\section{FOREIGN BOOKS}

Cambio de Mascara by Poli Delano. Casa de las Americas, Havana. (paperback). Play.

The Black Aesthetic edited by Addison Gayle, Jr. Charles E. Tuttle Co., Tokyo. (hardcover). In Japanese.

Senoras y Senores by Fernando Lamberg. Casa de las Americas, Havana. (paperback). Play.

Paul Valêry et le Théâtre by Huguette Laurenti. Editions Gallimard. (paperback).

El Asalto a Cuba por la Oligarquia Financiera Yanqui by Oscar Pino-Santos. Casa de las Americas, Havana. (paperback). Play.

Teatro Nello Spa Zio Degli Scontri by Gi uliano Scabia. Bulzoni Editoe, Rome. (paperback).

Una Casa en Lota Alto by Victor Torres. Casa de las Americas, Havana. (paperback).

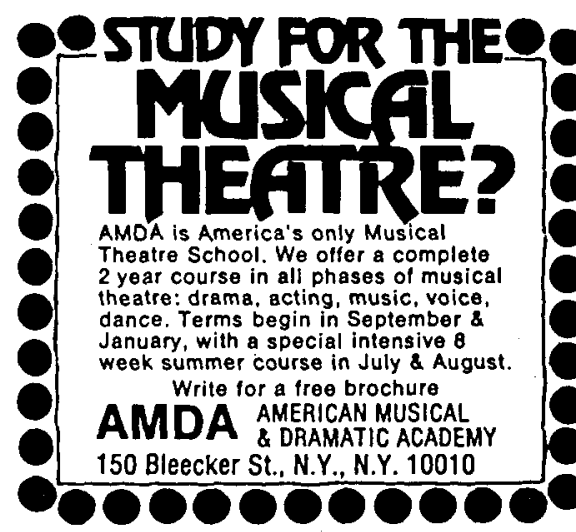

SONIA MOORE STUDIO OF THE THEATRE Fall Term Begins Sept. 29 Register Now

The only systematized acting technique

The up to date Stanislarski system taught by Director: ACSTA I Rep. Co. author "THE STANISLAVSKI SYSTEM" TRAINING AN ACTOR:

The Stanislavski System in Class Viking 1965; 1968

"STANISLAVSKI TODAY," ACSTA, 1973

For information \& interview: PL 5-5120

Day \& Evening Classes

Classes are held at the

Village Presbyterian Church, 139 West 13 Street.

\section{Theatrical Superstitions}

I have been commissioned by Taplinger, Inc., to write a book about superstitions in the theatre, the ballet, the film studio and the opera house, past and present, in America and abroad. 1 am interested in first night rituals, lucky mascots, theatrical ghosts and particularly the bad luck which is traditionally associated with "Macbeth."

I would be grateful for any help your readers can give me.

Richard Huggett c/o Georges Borchardt Agency 145 East 52nd St. New York, N.Y.

\begin{tabular}{l} 
VIOLA SPOLIN's \\
THEATER GAMES \\
taught by \\
STEPHEN BOOK \\
available for \\
Workshops at Your School \\
or Theater \\
Courses in New York \\
"I commend Stephen Book's work \\
as a valuable teacher of Spolin's \\
Theater Games." - VIoLA SPOLIN \\
A student of viola Spolin, and a \\
professional director, Stephen Book \\
teaches at the Circle in the Square \\
Theater School in New York. For the \\
past five years he has trained teach- \\
ers in the Spolin method of Impro- \\
visation at the Bread Loaf School of \\
English, Middlebury College. Other \\
institutions where he has taught \\
courses or workshops include: Stan- \\
ford, Princeton, AADA, Holderness, \\
and St. Marks of Dallas. \\
Address inquiries: \\
Lilli Purcell \\
158 W. 13th Street, N.Y. 10011 \\
212-691-8998 212-541-7600 \\
\hline
\end{tabular}

